\title{
The Influence of Nutrients on Turfgrass Response to Treated Wastewater Application, Under Several Saline Conditions and Irrigation Regimes
}

\author{
J. Beltrão • P. J. Correia • M. Costa • P. Gamito • \\ R. Santos • J. Seita
}

Received: 12 November 2013 / Accepted: 17 December 2013 / Published online: 24 April 2014

(C) Springer International Publishing Switzerland 2014

\begin{abstract}
The vast development of golf courses implemented in arid and semiarid regions, and the intense aquifer pumping rate of the water needed to irrigate these grass lands, provokes saline problems, mainly in the coastal areas, due to sea water intrusion. The reuse of treated wastewater to irrigate golf courses is considered as an alternative to the use of potable and ground water. The objective of this work was to study the response of Bermuda grass (Cynodon dactylon, L. Pers) to several irrigation rates I with reused treated municipal wastewater in two locations in southern Portugal. Three different irrigation regimes based on different values of electrical conductivity $\left(\mathrm{EC}_{\mathrm{w}}\right)$, namely $\mathrm{EC}_{\mathrm{w}}=0.3 \mathrm{dS} \mathrm{m}^{-1}$ (potable water; control treatment), $\mathrm{EC}_{\mathrm{w}}=1.6 \mathrm{dS} \mathrm{m}^{-1}$, and $\mathrm{EC}_{\mathrm{w}}=2.4 \mathrm{dS} \mathrm{m}^{-1}$, using the sprinkler point source as experimental design, were established. Grass yield (aboveground biomass) was recorded monthly, and linear regressions between yield and net irrigation rates I were obtained. The results showed a clear and pronounced influence of the nutrient concentration in wastewater on the response of the turfgrass irrigated under several water regimes and saline conditions. Higher irrigation rates ( $\mathrm{I}>6 \mathrm{~mm} \mathrm{~d}^{-1}$ ) triggered higher yields, but this increase was slightly lower under higher salinity conditions $\left(\mathrm{EC}_{\mathrm{w}}=2.4 \mathrm{dS} \mathrm{m}^{-1}\right)$. We conclude that wastewater can be used to irrigate turfgrass as an alternative to potable water due to the presence of significant quantities of some essential nutrients, like K. However, the EC of wastewater can be a limiting factor.
\end{abstract}

\footnotetext{
J. Beltrão

Research Centre for Spatial and Organization Dynamics, Faculty of Sciences and Technology, University of Algarve, Campus of Gambelas, 8005-139 Faro, Portugal e-mail: jbeltrao@ualg.pt

P. J. Correia $(\square)$

ICAAM, Faculty of Sciences and Technology, University of Algarve, Campus of Gambelas, 8005-139 Faro, Portugal

e-mail: pcorreia@ualg.pt

M. Costa $\cdot$ P. Gamito $\cdot$ R. Santos $\cdot$ J. Seita

Faculty of Sciences and Technology, University of Algarve, Campus of Gambelas, 8005-139 Faro, Portugal

M. Costa

e-mail: mscosta2000@hotmail.com
} 
Keywords Bermuda grass · Golf course $\cdot$ Nitrogen $\cdot$ Potassium $\cdot$ Turfgrass yield $\cdot$ Salinization

\section{Introduction}

Due to the lack of water in the arid and semiarid areas in the coastal regions, potable and fresh water luxurious uses are increasingly contested. In order to solve this problem, groundwater gained an increasing role in the planning and in the development of additional water supplies (Hamdy 2002). Its use for irrigation purposes has reduced the crop yields (Ben Asher et al. 2002; Ayars et al. 2006), increased the soil salination and deteriorated the soil structure and permeability (Shainberg et al. 2002). Yield reduction occurs when the salts accumulate in the root zone to such an extent that the crop is no longer able to extract sufficient water from the salty soil solution, resulting in a water stress for a significant period of time (Ayers and Westcot 1985). The equation relating relative yield (Yr, dimensionless $0-1)$ and the electrical conductivity of the irrigation water $\mathrm{EC}_{\mathrm{w}}\left(\mathrm{dS} \mathrm{m}^{-1}\right)$ is the following (Maas and Hoffman 1977):

$$
\mathrm{Yr}=1-\mathrm{b}\left(\mathrm{EC}_{\mathrm{w}}-\mathrm{a}\right)
$$

where $a$ is the crop tolerance represented by the threshold salinity value $\left(\mathrm{dS} \mathrm{m}^{-1}\right), \mathrm{b}$ is the crop sensitivity represented by the slope (rate of yield reduction per unit of salinity), and $\mathrm{EC}_{\mathrm{w}}$ is the electrical conductivity of irrigation water. Crops produce at their full potential yield until salinity reaches a threshold value, which is the maximum average salt concentration in the root zone that does not reduce the yield; above the threshold value, the yield decreases as a linear function of salinity until the plants die when it drops sharply to zero.

Beside the fertilization capacity of the different nutrients, there is clear nutrient-salt interaction and plant growth (Silberbush et al. 1988). Hence, the use of enhanced nitrogen fertilization is a potential tool in precluding salt induced stress in many crops (Feigin 1985). In addition, potassium has also a high contribution in alleviating salinity problems (Wakeel 2013).

Experimental studies related to nutrient-salt interactions, and plant growth and quality were completed for several plants, including: horticultural crops (Prazeres et al. 2013; Saykhul et al. 2013), leguminous crops (Correia et al. 2010; Bulut et al. 2011) and grasses (Morshedi and Farahbakhish 2012). It was shown that yield response to salinity tolerance is not always a constant as the model of Maas and Hoffman (1977) suggests, but fertilization increases tolerance to salinity (salinity threshold value); however, at high salinity levels, the osmotic effect is more pronounced and enhanced fertilization may provoke a negative effect on crop yield (Beltrão et al. 2002). The general plant physiological mechanisms for these nutrient-salt interaction phenomena were explained by Grattan and Grieve (1999). Studies related to the combined effects of salinity and fertilizers, were also undertaken for grasses (Sagi et al. 1996, 1997).

The reuse of treated wastewater is considered as an alternative to the use of potable water in Mediterranean agriculture and landscape (Carr et al. 2011), especially in golf courses (Salgot et al. 2012). Hence, according to the development of the construction of golf courses in coastal areas, several studies were undertaken on the response of Bermuda grass (Cynodon dactylon, L. Pers) to the reuse of treated municipal wastewater. This response was generally expressed by the yield. It was observed that the minimal yield for the good visual appearance (GVA) of Bermuda grass was around $9,000 \mathrm{~kg} \mathrm{ha}^{-1}$ month $^{-1}$ (Beltrão et al. 1999). However, Costa (2004) observed that grass quality is not only directly related to grass yield, but also it depends on some other environmental factors involved, such as the climate, water and nutrients, and 
soil salinity, being the grass quality one of the best parameters to qualify the appearance of the lawns.

This study focused on the response of Bermuda grass irrigated with municipal treated wastewater in two different locations in southern Portugal (Algarve). Taking into consideration the chemical composition of this irrigation water, which includes some essential macronutrients and other ions, it is expected that yield can be ensured avoiding the excessive use of fertilizers.

\section{Materials and Methods}

\subsection{Site and Turfgrass}

The experiments were carried out in the Salgados golf course and on the Campus of Penha, University of Algarve, Portugal, from May up to the end of July.

The Bermuda turfgrass Cynodon dactilon, was selected for this study, single or consociated with other species, because it is the most frequently used cultivar in fairways and roughs of golf courses, and it represents their largest area. Cynodon dactilon, 'Bermuda 419' and 'Savanna' are the most commonly used species on the Mediterranean golf courses. "Savanna" is exclusively applied on the roughs; on the other hand, "Bermuda 419", which is most used, is grown on tees and fairways (Beltrão et al. 2009). They are warm-season species, adapted to a wide range of soil conditions, even though Bermuda grass is generally not cold tolerant. Its intolerance to shade necessitates the use of alternative warm-season species on sites where trees and other structures restrict sunlight penetration (Beard 1982); these species are perennial, have a long life, quick growth at $18-35^{\circ} \mathrm{C}$, but become brown when temperature decreases. Its growth is extremely vigorous compared to other species (Mateo Box and Urbano 1985).

\subsection{Soil and Water Quality Parameters}

The experiments were conducted in fluvisols, containing approximately $30 \%$ of clay, similar to the soil types of the local fairways and roughs of most of the golf courses located in the region of Algarve. According to water sources and to the location of the experimental sites, there were three different water treatments, as follows: Potable water $\mathrm{S} 0\left(\mathrm{EC}_{\mathrm{w}}=0.3 \mathrm{dS} \mathrm{m}^{-1}\right)$ on Campus da Penha, Wastewater WW1 S1 $\left(\mathrm{EC}_{\mathrm{w}}=1.6 \mathrm{dS} \mathrm{m}^{-1}\right)$ in Salgados Golf course, and Wastewater WW2 S2 $\left(\mathrm{EC}_{\mathrm{w}}=2.4 \mathrm{dS} \mathrm{m}^{-1}\right)$ on Campus da Penha. Table 1 shows the concentration of typical chemical parameters. The values of the electrical conductivity $\mathrm{EC}_{\mathrm{w}}$ were higher in wastewater, as expected. Potassium $(\mathrm{K})$ concentration of the wastewater was very high, equivalent to a very high $\mathrm{K}$ mineral fertilization; on the other hand, nitrogen $(\mathrm{N})$ concentration was low, probably due to prior biological treatment, where microorganisms consumed high quantities of $\mathrm{N}$ needed for their metabolism.

\subsection{Climate and Water Regimes}

The climate of Algarve, particularly the south shore, can be considered as Mediterranean. According to Köppen (1936), it is classified as Csa, with semi-arid characteristics, identified by mild rainy winters and by warm and dry summers. Snow and frost are not common. The annual average temperature, in Faro, ranges between $12^{\circ} \mathrm{C}$ in January and $23^{\circ} \mathrm{C}$ in August, a difference of only $11^{\circ} \mathrm{C}$. 
Table 1 Concentration of some parameters in irrigation water

\begin{tabular}{lccc}
\hline Irrigation & Potable & WW1 & WW2 \\
Parameters & Water S0 & $\mathrm{S} 1$ & $\mathrm{~S} 2$ \\
\hline $\mathrm{pH}$ & 7.0 & 7.4 & 7.2 \\
$\mathrm{EC}$ & $\left(\mathrm{dS} \mathrm{m}^{-1}\right)$ & 1.6 & 2.4 \\
$\mathrm{CO}_{3}{ }^{2-}\left(\mathrm{mg} \mathrm{L}^{-1}\right)$ & 0.3 & 0 & 0 \\
$\mathrm{HCO}_{3}^{-}\left(\mathrm{mg} \mathrm{L}^{-1}\right)$ & 0 & 470 & 350 \\
$\mathrm{Na}^{+}\left(\mathrm{mg} \mathrm{L}^{-1}\right)$ & 90 & 198 & 33 \\
$\mathrm{~K}^{+}\left(\mathrm{mg} \mathrm{L}^{-1}\right)$ & 12 & 112 & 84 \\
$\mathrm{Mg}^{2+}\left(\mathrm{mg} \mathrm{L}^{-1}\right)$ & 2 & 42 & 23 \\
$\mathrm{Ca}^{2+}\left(\mathrm{mg} \mathrm{L}^{-1}\right)$ & 6 & 70 & 217 \\
$\mathrm{Cl}^{-}\left(\mathrm{mg} \mathrm{L}^{-1}\right)$ & 26 & 100 & 175 \\
$\mathrm{NO}_{3}^{-}\left(\mathrm{mg} \mathrm{L}^{-1}\right)$ & 20 & 1.2 & 5.0 \\
$\mathrm{NO}_{2}{ }^{2-}\left(\mathrm{mg} \mathrm{L}^{-1}\right)$ & 0.5 & 0.6 & 0 \\
$\mathrm{NH}_{4}{ }^{+}\left(\mathrm{mg} \mathrm{L}^{-1}\right)$ & 0 & 0 & 0 \\
$\mathrm{P}_{2} \mathrm{O}_{5}\left(\mathrm{mg} \mathrm{L}^{-1}\right)$ & 0 & 7 & 2 \\
\hline
\end{tabular}

Table 2 shows the most important climatic parameters - temperature, Penman potential evapotranspiration and precipitation (30 years average) of the coastal area of Algarve, where the study was carried out. The annual value for potential evapotranspiration was $1,280 \mathrm{~mm}$, and the precipitation was around $500 \mathrm{~mm}$. In addition, the values of potential evapotranspiration and precipitation show opposite distribution during the year. During the hottest semester, when the photosynthesis is more efficient and the water is more essential for plant growth, precipitation is less available; irrigation is the only solution to balance this situation (Costa et al. 2011). The average of water shortage, defined as the difference between the rates of evapotranspiration and precipitation, verified between

Table 2 Climatic parameters (1970-2000)

\begin{tabular}{lccc}
\hline Month & Mean Temperature $\left({ }^{\circ} \mathrm{C}\right)$ & ETP $(\mathrm{mm})$ & Rainfall Depth $(\mathrm{mm})$ \\
\hline January & 11.3 & 33 & 61 \\
February & 12.2 & 39 & 52 \\
March & 14.3 & 81 & 72 \\
April & 15.2 & 117 & 30 \\
May & 17.8 & 164 & 21 \\
June & 20.9 & 183 & 5 \\
July & 23.8 & 208 & 1 \\
August & 23.4 & 189 & 0 \\
September & 21.5 & 120 & 18 \\
October & 18.4 & 84 & 61 \\
November & 14.9 & 36 & 65 \\
December & 12.6 & 25 & 67 \\
YEAR & 17.2 & 1280 & 453 \\
\hline
\end{tabular}

ETP: evapotranspiration 
March and October, may reach $940 \mathrm{~mm}$ per year. The daily water balance equation for the root zone is given by:

$$
\mathrm{I}+\mathrm{P}+\mathrm{CR}=\mathrm{ET}_{\mathrm{a}}+\mathrm{D}_{\mathrm{r}}+\mathrm{R}+\Delta \mathrm{S}
$$

where $\mathrm{I}$ is the net irrigation, $\mathrm{P}$ is the precipitation, $\mathrm{CR}$ is the capillary rise from the groundwater table to the root zone, $\mathrm{ET}_{\mathrm{a}}$ is the actual seasonal average evapotranspiration, $\mathrm{D}_{\mathrm{r}}$ is the drainage below the root zone, $\mathrm{R}$ is the runoff, and $\Delta \mathrm{S}$ is the change in water storage within the root zone; the units for all these parameters are $\mathrm{mm} \mathrm{d}^{-1}$. Capillary rise $\mathrm{CR}$ and runoff $\mathrm{R}$ were zero during the experimental period, natural precipitation $\mathrm{P}$ was negligible, and $\Delta \mathrm{S} \sim 0$ due to the high irrigation frequency (daily). Hence, Eq. (2) is simplified to:

$$
\mathrm{I}=\mathrm{ET}_{\mathrm{a}}+\mathrm{D}_{\mathrm{r}}
$$

During the experimental period, the net irrigation water rate I was applied daily and its average value was computed as follows:

a) For $\mathrm{I}<6 \mathrm{~mm} \mathrm{~d}^{-1}, \mathrm{ET}_{\mathrm{a}}=\mathrm{ET}_{\mathrm{c} ., \mathrm{adj}}, \mathrm{D}_{\mathrm{r}}=0$ (no drainage effects)

$$
\mathrm{I}=\mathrm{ET}_{\mathrm{c}, \text { adj }}=\mathrm{K}_{\mathrm{s}} \cdot \mathrm{K}_{\mathrm{c}} \cdot \mathrm{ET}_{0}
$$

b) For $\mathrm{I}=6 \mathrm{~mm} \mathrm{~d}^{-1}, \mathrm{ET}_{\mathrm{a}}=\mathrm{ET}_{\mathrm{c}}, \mathrm{D}_{\mathrm{r}}=0$ (no drainage effects)

$$
\mathrm{I}=\mathrm{ET}_{\mathrm{c} .}=\mathrm{K}_{\mathrm{c}} \cdot \mathrm{ET}_{0}
$$

c) For I $>6 \mathrm{~mm}, \mathrm{ET}_{\mathrm{a}}=\mathrm{ET}_{\mathrm{c} .}, \mathrm{Dr}>0$ (drainage effects)

$$
\mathrm{I}=\mathrm{ET}_{\mathrm{c} .}+\mathrm{D}_{\mathrm{r}}=\mathrm{K}_{\mathrm{c}} \cdot \mathrm{ET}_{0}+\mathrm{D}_{\mathrm{r}}
$$

where $\mathrm{ET}_{\mathrm{c} . \text {,adj }}$ is the adjusted evapotranspiration under non-standard conditions and its value is used when the crop is under stress conditions (Allen et al. 1998); $\mathrm{K}_{\mathrm{c}}$ is the crop coefficient under the standard conditions (Doorenbos and Pruitt 1984), $\mathrm{ET}_{0}$ is the average reference evapotranspiration (Penman-Monteith), and $\mathrm{K}_{\mathrm{s}}$ (dimensionless 0-1) describes the effect of crop stress on crop evapotranspiration $\mathrm{ET}_{\mathrm{c}}$. The estimation of these crop coefficients and crop factors, useful to the definition of crop production systems and characterized by the link between the production and the water application, have been developed by Allen and Pereira (2009), Allen et al. (2011a, b) and Pereira et al. (2012).

In order to simulate different irrigation regimes, a sprinkler point source experimental design was used (Fig. 1). This design is based on the assumption that a point creates a linear irrigation gradient from the water point source obtained from a triangular sprinkler water diagram, producing a gradual change in water application, (Hartman and Zengerl 1985; Or and Hanks 1992). The wettest zone was near the sprinkler and the treatments near the borders were the driest. The irrigation system was stopped when wind speed was larger than $1 \mathrm{~m} \mathrm{~s}^{-1}$. A 323/ 90 Naan sprinkler was used, with 2.4 x $4.8 \mathrm{~mm}$ diameter nozzles, using a $250 \mathrm{kPa}$ sprinkler pressure, with a wetting radius of about $10 \mathrm{~m}$. Christiansen uniformity coefficient CUC (Christiansen 1942) was used to determine the uniformity of water distribution at 2, 4, 6, 


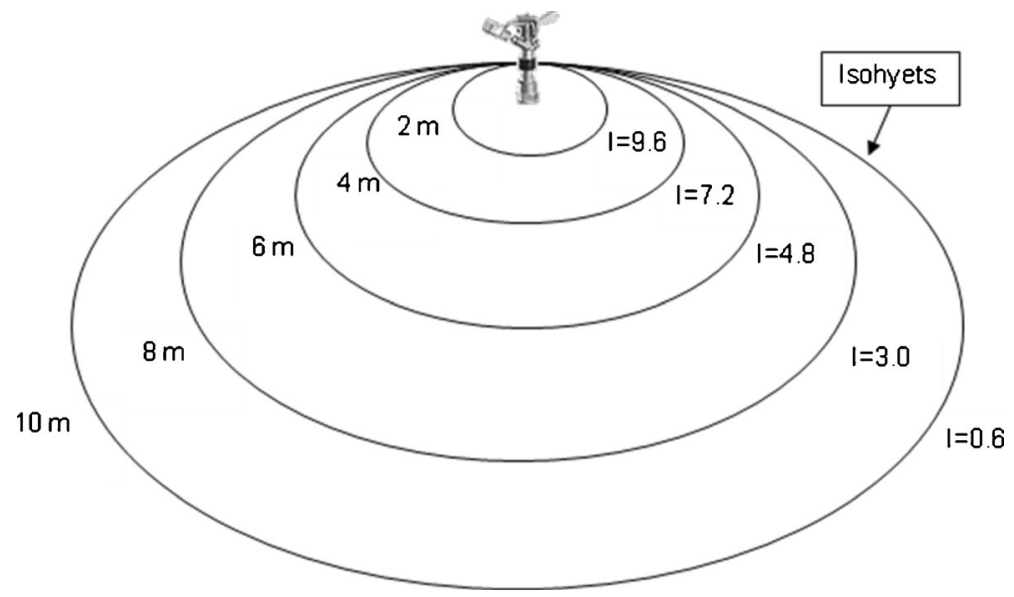

Fig. 1 Point source experimental design applied in the Salgados golf course. Irrigation gradient was expressed by the daily net irrigation rates $\left(\mathrm{I}, \mathrm{mm} \mathrm{d}^{-1}\right)$ and the distance from the sprinkler in $\mathrm{m}$

and $8 \mathrm{~m}$ from the sprinkle point source; the respective CUC values obtained were 94, 93, 92, and $80 \%$. The plots were irrigated once a day.

The colour is one of the best indicators of the aspect-quality of turfgrass (Turgeon 1980). Hence, a colour visual method was used to define the turfgrass quality (Mantell and Stanhill 1981), associated to the sprinkler point source design. The appearance of the lawn was compared with the observation of the colour values of "Standard Soil Colour Charts" (Munsell 1991). The grass yields, under different irrigation quantities, were sampled monthly. The grass was mowed with scissors and collected at the predetermined distance from the sprinkler.

\subsection{Statistical Analysis}

The effects of treatments were evaluated using the analysis of variance (ANOVA), when no cause and effect relationship is known. The statistical test Dunnett T3 was selected, in order to identify the statistical difference among multiple mean values at the $95 \%$ significance level. SPSS 11.0 (2002) was used. When problems of lack of randomization were known due to the point source experimental design, a geostatistical approach was undertaken, according to Panagopoulos et al. (2006).

\section{Results and Discussion}

Figure 2 shows the Bermuda turfgrass response to wastewater and potable water application, from May up to the end of July, for the three trials (potable water PWS0 - $\mathrm{EC}_{\mathrm{w}}=0.3 \mathrm{dS} \mathrm{m}{ }^{-1}$ ), wastewater WWS1 $-\mathrm{EC}_{\mathrm{w}}=1.6 \mathrm{dS} \mathrm{m}{ }^{-1}$ ), and wastewater WWS2 $-\mathrm{EC}_{\mathrm{w}}=2.4 \mathrm{dS} \mathrm{m}^{-1}$ ). For low irrigation water quantities $\left(\mathrm{I}<3 \mathrm{~mm} \mathrm{~d}^{-1}\right.$ ), water was the limiting factor; the yield was sharply enhanced with increasing rate of water application. Grass yield response was lower on the WWS2 treatment near the dry level and higher on the PWS0 treatment, due to the higher osmotic pressure of the soil. For intermediate water quantities $\left(3 \mathrm{~mm} \mathrm{~d}^{-1}<\mathrm{I}<6 \mathrm{~mm} \mathrm{~d}^{-1}\right)$, wastewater application triggered slightly higher yields compared to potable water application, particularly if $\mathrm{I}$ is close to $6 \mathrm{~mm} \mathrm{~d}^{-1}$. This was probably due to the lower concentration of 


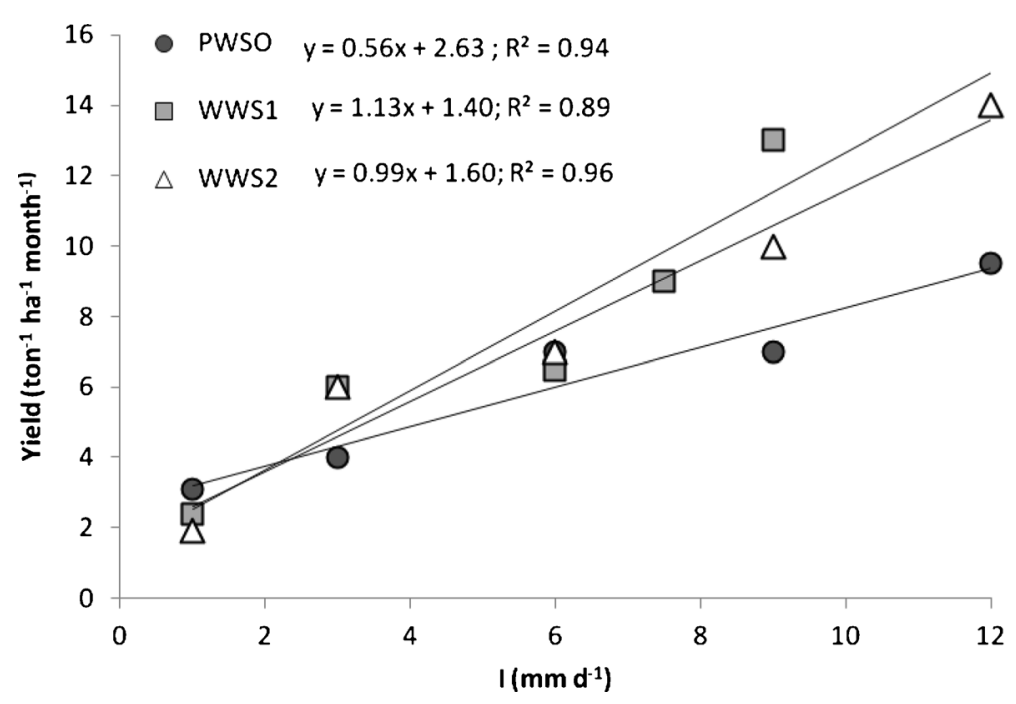

Fig. 2 Comparative turfgrass responses to potable water (PWS0) and wastewater (WWS1 and WWS2). Irrigation is expressed by the net irrigation water rates $\mathrm{I}\left(\mathrm{mm} \mathrm{d}^{-1}\right)$

nutrients of the potable water when compared to wastewater (Table 1). For high water quantity application $\left(\mathrm{I}>6 \mathrm{~mm} \mathrm{~d}^{-1}\right)$, there were increased yields in the three treatments. The sensitivity of the yield to water was higher in the WWS1 treatment (sharp increase), due to the lower salinity level when compared to treatment WWS2, explained by soil leaching. On the other hand, the enhancement was lower for the PWS0 treatment (monotonic increase), due to its lower concentration of nutrients combined with soil leaching.

By comparing visually the same grass yield quantity coming from the different treatments, it is recognized that grass quality was not only related to the grass yield but also on several environmental factors involved on grass growth, such as climate, water, nutrients (particularly $\mathrm{N}$ and $\mathrm{K}$ ) and salinity. Hence, generally, at values of $\mathrm{I}>5.4 \mathrm{~mm} \mathrm{~d}^{-1}$, a good quality of the lawns was verified. But also in some cases, a good visual appearance of the grass was seen for lower values of I, i.e., 4 or $5 \mathrm{~mm} \mathrm{~d}^{-1}$, according to Costa (2004).

The presence of nutrients in wastewater can decrease or even avoid mineral fertilization. However, at low water quantity application, the grass yield response was lower with wastewater treatments, due to the higher osmotic pressure of the soil. On the other hand, for wetter regimes, when the salinity of wastewater reached higher values $\left(\mathrm{EC}_{\mathrm{w}}=2.4 \mathrm{dS} \mathrm{m}^{-1}\right)$, the rate of the yield increase was lower due to the detrimental effect of salinity. This effect was most probably attributed to the presence of $\mathrm{Cl}$ in WW2 treatment. In golf courses the costs of lawns maintenance (such as cuts frequency and fertilizers application) are high. Therefore, reducing turfgrass growth but simultaneously maintaining a good visual appearance, may contribute to reduce these costs. This can be achieved by using wastewater application providing that chemical and microbiological properties are not limiting.

\section{Conclusions}

A high research priority must be given on the response of grass quality to environmental factors (including irrigation and fertilization) in order to maintain the sustainability and the 
good appearance of golf courses in the Mediterranean area. Experimental results and discussion have confirmed that yield improves as net irrigation increases. Higher concentrations of macronutrients, like $\mathrm{K}, \mathrm{Ca}$ and $\mathrm{Mg}$, in the wastewater, either WWS1 or WWS2, enhanced turfgrass yield. The high $\mathrm{K}$ concentration of the wastewater may also improve the soil structure, with benefits to the soil hydraulic properties, which interfere with the transport of water to the roots, and therefore, with turfgrass development.

Acknowledgments This work was partially supported by the CIEO - Research Centre for Spatial and Organizational Dynamics, and ICAAM - "Instituto de Ciências Agrárias e Ambientais Mediterrânicas", University of Algarve, Salgados Golf Course and Foundation for Science and Technology, Portugal. An initial version of this paper was presented at the 8th International Conference of the EWRA in Porto, Portugal, June 2629, 2013.

\section{References}

Allen RG, Pereira LS (2009) Estimating crop coefficients from fraction of ground cover and height. Irrig Sci 28 : 17-34

Allen RG, Pereira LS, Raes D, Smith M (1998) Crop evapotranspiration. Guidelines for computing crop water requirements. FAO Irrig. Drain. Paper 56, Rome, Italy.

Allen RG, Pereira LS, Howell TA, Terry A, Jensen ME (2011a) Evapotranspiration information reporting: I. Factors governing measurement accuracy. Agric Water Manage 98:899-920

Allen RG, Pereira LS, Howell TA, Terry A, Jensen ME (2011b) Evapotranspiration information reporting: II. Recommended documentation. Agric Water Manage 98:921-929

Ayars J, Christen EW, Soppe RW, Meyer WS (2006) The resource potential of in-situ shallow ground water use in irrigated agriculture. Irrig Sci 24:147-160

Ayers RS, Westcot DW (1985) Water quality to agriculture. FAO Irrig. Drain. Paper. 29. Rome, Italy.

Beard JB (1982) Turfgrass management for golf courses. Prentice Hall, Englewood Cliffs, USA

Beltrão J, Gamito P, Guerrero C, Arsénio A, Brito JMC (1999) Grass response to municipal wastewater as compared to nitrogen and water application. In: Anaç D, Martin-Prével P (Eds) Improved Crop quality by Nutrient management, Kluwer Academic Publishers pp 263-266

Beltrão J, Jesus SB, Trindade D, Miguel MG, Neves MA, Panagopoulos T, Ben Asher J (2002) Combined effects of salts and nitrogen on the yield function of Lettuce. Acta Hort 573:363-368

Beltrão J, Brito J, Neves MA, Seita J (2009) Salt removal potential of Turfgrasses in golf courses in the Mediterranean basin. WSEAS Transactions on Environment and Development 5(5):394-403

Ben Asher J, Beltrão J, Costa M, Anaç S, Cuartero J, Soria T (2002) Modeling the effect of sea water intrusion on ground water salinity in agricultural areas in Israel, Portugal, Spain and Turkey. Acta Hort 573:119-128

Bulut F, Akinci S, Eroglu A (2011) Growth and uptake of sodium and potassium in broad bean (Vicia faba L.) under salinity stress. Comm Soil Sci Plant Anal 42:945-961

Carr G, Potter RB, Nortcliff S (2011) Water reuse for irrigation in Jordan: perceptions of water quality among farmers. Agric Water Manag 98:847-854

Christiansen J (1942) Irrigation by sprinkling. Calif. Agron. Esp. Bulletin 640. USA.

Correia PJ, Gama F, Pestana M, Martins-Loução MA (2010) Tolerance of young carob-tree rootstocks to NaCl. Agric Water Manag 97:910-916

Costa M (2004) Wastewater reuse in the Algarve region. Dissertation Ph.D. Thesis. University of Algarve, Faro, Portugal.

Costa M, Beltrão J, Brito JMC, Guerrero C (2011) Turfgrass plant quality response to different water regimes. WSEAS Transactions on Environment and Development 7(6):167-176

Doorenbos J, Pruitt WO (1984) Guidelines for predicting crop water requirements. FAO Irrig. Drain. Paper 24. Rome, Italy.

Feigin A (1985) Fertilization management of crops irrigated with saline water. Plant soil 82:285-299

Grattan SR, Grieve CM (1999) Salinity-mineral nutrient relations in horticultural crops. Sci Hortic 78:127-157

Hamdy A (2002) Sustainable use and management of non-conventional water resources in the arid regions. Acta Hort 573:159-174 
Hartman HD, Zengerl KH (1985) New method to optimize the irrigation. Gemuse 5:227-229 (In German)

Köppen W (1936) The geographical system of climate. Germany, Berlin (In German)

Maas EV, Hoffman GJ (1977) Salt crop tolerance - current assessment. Irrig Drain Div, Am Soc Civil Eng 103: 115-134

Mantell A, Stanhill G (1981) Lawngrass. In: Irrigation of field and orchard crops under semi-arid conditions Shalhevet J, Mantell A; Bielorai H, Shimshi D (eds) (2nd edition) III C, Volcani Center, Bet Dagan, Israel.

Mateo Box JM, Urbano P (1985) The Turfgrasses. 2nd ed. Madrid, Spain (In Spanish)

Morshedi A, Farahbakhish H (2012) The role of potassium and zinc in reducing salinity and alkalinity stress conditions in two whet genotypes. Arch Agron Soil Sci 58:371-384

Munsell (1991) Standard soil colour charts. Revised. Eijkelkamp Agrisearch Equipment (ed) Giesbeek, Netherlands.

Or D, Hanks RJ (1992) A single point source for the measurement of irrigation production functions. Irrig Sci 13: 55-64

Panagopoulos T, Jesus J, Antunes MDC, Beltrão J (2006) Analysis of spatial interpolation for optimising management of a salinized field cultivated with lettuce. Eur J Agro 24:1-10

Pereira LS, Cordery I, Iacovides I (2012) Improved indicators of water use performance and productivity for sustainable water conservation and saving. Agric Water Manag 108:39-51

Prazeres AR, Carvalho F, Rivas J, Patanita L, Dores J (2013) Pre-treated cheese whey wastewater management by agricultural reuse: chemical characterization and response of tomato plants Licopersicon esculentum Mill, under salinity conditions. Sci Total Enviro 63:943-951

Sagi M, Savidov N, L'vov NP, Lips SH (1996) Nitrate reductase and molybdenum cofactor in annual ryegrass as affected by salinity and nitrogen source. Physiol Plantarum 99:546-553

Sagi M, Dovrat A, Kipnis T, Lips SH (1997) Ionic balance and the production of biomass and organic nitrogen as affected by salinity and N source in annual ryegrass (Lolium multiflorum Lam). J Plant Nut 20:1291-1316

Salgot M, Priestley G, Folch M (2012) Golf course irrigation with reclaimed water in the Mediterranean: a risk management matter. Water 4:389-429

Saykhul A, Chatzistathis T, Chatzissavvidis C, Koundouras S, Therios I, Dimas K (2013) Potassium utilization efficiency of three olive cultivars grown in a hydroponic system. Sci Hortic 162:55-62

Shainberg G, Levy J, Mamedov AI (2002) Prewetting rate and sodicity effects on soil permeability and surface sealing. Acta Hort 573:21-28

Silberbush M, Ben-Asher J, Lips SH (1988) Nutrient-salt interactions and plant growth. Advances in Desert and Arid Land Technology and Development, 5:631-645. Harwood Academic Publishers, New York.

SPSS (2002) SPSS Inc, Chicago, Illinois, U.S.A.

Turgeon A (1980) Turfgrass management. Prentice Hall, Engelwood Cliffs, USA

Wakeel A (2013) Potassium-sodium interactions in soil and plant under saline-sodic conditions. J Plant Nutr Soil Sci 176:344-354 